Pyroxene. The two clinopyroxenes analysed - one from a pyroxene-garnet vein in anorthosite (coexisting with garnet no. 7 above), the other from pyribolite (cf. coexisting garnet no. 3) - are salites of similar compositions, $\mathrm{Ca}_{49} \mathrm{Mg}_{31} \mathrm{Fe}_{20}$ and $\mathrm{Ca}_{46} \mathrm{Mg}_{34} \mathrm{Fe}_{20}$, respectively. Orthopyroxene from hypersthene gneiss of the Hellefiske Øer is a hypersthene of composition $\mathrm{Ca}_{1} \mathrm{Mg}_{52} \mathrm{Fe}_{47}, \mathrm{Al}_{2} \mathrm{O}_{3} 1.8 \%$.

Amphiboles from two specimens of anorthosites - one gabbroic, the other layered - were analysed. Both are magnesio-hornblendes (classification of Leake, 1968) and have the formula $\left(\mathrm{Ca}_{1.7-1.8} \mathrm{Na}_{0.3} \mathrm{~K}_{0.1-0.04}\right)\left(\mathrm{Fe}_{1.6} \mathrm{Ti}_{0.1} \mathrm{Mg}_{2.9-3.1}\right)\left(\mathrm{Si}_{6.6-6.8} \mathrm{Al}_{1.4-1.2}\right) \mathrm{O}_{23}$. (Chromium was sought but not found).

Plagioclase coexisting with the amphiboles is $\mathrm{An}_{79-82}$. (Iron and chromium were sought but not detected).

\title{
References
}

Ghisler, M. \& Windley, B. F. 1967: The chromite deposits of the Fiskenæsset region, West Greenland. Rapp. Gronlands geol. Unders. 12, 38 pp.

Leake, B. E. 1968: A catalog of analyzed calciferous and subcalciferous amphiboles together with their nomenclature and associated minerals. Spec. Pap. geol. Soc. Am. 98.

\section{FIELD INVESTIGATIONS IN THE JULIANEHÅB GRANITE ON THE NUNATAKS NORTH-WEST, NORTH AND EAST OF NARSSARSSUAQ, SOUTH GREENLAND}

\author{
Jan H. Allaart
}

\section{Pre-Gardar basement}

Before the compilation of the Narssarssuaq sheet $(1: 100000)$ could be finished, about $900 \mathrm{~km}^{2}$ of high mountainous terrain in the north-western, northern and eastern parts of the sheet area had to be mapped.

Important occurrences of supracrustal rocks have been found in three different places. One, north-west of Narssarssuaq, consists of interbanded amphibolite, semipelitic gneiss and aplitic gneiss. The two other occurrences, both in the north, consist of acid and also some intermediate porphyritic metavolcanics alternating with layers of pyroclastic rocks and aplitic gneiss.

An area exclusively consisting of aplitic gneiss has also been mapped north-west of Narssarssuaq. The original supracrustal characteristics of this gneiss are not evident, but the close similarity to the aplitic gneiss associated with the acid meta- 
volcanics suggests that it belongs to the same supracrustal series, probably representing a recrystallisation product of the acid metavolcanic rocks.

The acid metavolcanics and the aplitic gneiss are all enveloped by a leucocratic fine- to medium-grained granodiorite or adamellite which characteristically contains very small crystals of biotite and regularly distributed, small aggregates of biotite, with or without hornblende. This granite, which is the main variety in most of the northern part of the Narssarssuaq sheet (Walton, 1965), is usually unfoliated, but in some areas foliation and also compositional banding is still preserved.

Another variety of wide distribution is a gneissose hornblende-biotite granodiorite with many oriented dark inclusions and in some places with folded leucocratic veins which clearly predate the foliation. Large areas of this variety have been recorded in the easternmost part of the sheet area, but it also forms relics in a variety of weakly foliated medium- to coarse-grained hornblende-biotite granodiorite and also in a monzonitic variety in the north-west.

Various basic to intermediate intrusions have been mapped in the Julianehåb granite. The most important one is a zoned diorite - hypersthene monzonite intrusion east of Motzfeld Sø, which is like those described by Walton (1965) in the central and northern part of the sheet. The present one had already been noted by Emeleus \& Harry $(1970$, p. 17).

Typical appinites (hornblende megacryst rocks) with associated coarse-grained pyroxenites occur in different places in different types of granite and also in aplitic gneiss. East of Narssarssuaq it could be shown that these rocks post-date the zoned diorite-monzonite intrusion while they themselves are closely associated with an important intrusion of aplitic granite which has cut off almost half of the zoned dioritemonzonite body.

In the monzonitic variety of Julianehåb granite in the nunataks north-west of Narssarssuaq a gabbro intrusion has been mapped and also masses of dioritic and other basic material which were so strongly veined by the monzonite and transformed that their original characters are hardly recognisable. The age relations of these rocks to the zoned diorite-monzonite intrusions and the appinites which are supposed to be relatively young, is not known. They could be very much older.

\section{Gardar rocks}

On the nunataks in the north-west an important ENE-trending swarm of at least 20 dykes with a total width of more than $500 \mathrm{~m}$ has been recorded. The dykes consist of dolerites, big-feldspar dykes and one or two microsyenites. This swarm represents the north-eastern continuation of the Gardar swarm of the Nunarssuit region (see GGU 1:100 000 sheet 60 V. 1 Nord, Nunarssuit). Moreover two E-W to ESE-trending swarms, each consisting of three dolerite dykes, have been mapped with a total thickness exceeding $300 \mathrm{~m}$.

North-east of Narssarssuaq an important composite dyke 0.5-1 km wide occurs 
with gabbro margins and syenite in its centre. This dyke could be followed over at least $25 \mathrm{~km}$ and occurs north of Geologfjeld where A. Weidick already noted its presence (see Emeleus \& Harry, 1970, p. 16), and on G. F. Holm Nunatak.

Finally, observations on the great Gardar swarm around Narssarssuaq and Qagssiarssuk showed that in the densest parts of the swarm the dykes take up to $16 \%$ of the space perpendicular to their trend.

\section{References}

Emeleus, C. H. \& Harry, W. T. 1970: The Igaliko nepheline syenite complex. General description. Bull. Gronlands geol. Unders. 85 (also Meddr Gronland 186, 3) 115 pp.

Walton, B. J. 1965: Sanerutian appinitic rocks and Gardar dykes and diatremes, north of Narssarssuaq, South Greenland. Bull. Gronlands geol. Unders. 57 (also Meddr Grønland 179, 9) 66 pp.

\section{HEAT FLOW INVESTIGATIONS IN THE NARSSAQ AND IVIGTUT AREAS}

\section{Bjarne Leth Nielsen}

Temperature measurements in drill holes have been carried out in the Ivigtut area and in the Ilímaussaq intrusion near Narssaq as the start of a general heat flow investigation in South Greenland. As this kind of work has not previously been done in Greenland and heat flow data from arctic areas are still very few it is hoped that the results will contribute to a better understanding of world-wide heat flow patterns and their relationship to major tectonic provinces.

The apparatus used, borrowed from the U. S. Geological Survey, consisted of a thermistor probe connected to a Wheatstone bridge at the surface where the thermistor resistance values were compensated. Measurements were taken at $10 \mathrm{~m}$ intervals both upwards and downwards and the mean values plotted in the temperature profiles.

In the Ivigtut area two drill holes were measured - Dh M $(500 \mathrm{~m})$ and $\mathrm{Dh} \mathrm{O}(200 \mathrm{~m})$. They are both situated in the Ivigtut valley. The cores consist of Ivigtut gneiss reworked during the Ketilidian. The four holes measured in the llímaussaq intrusion are Dh 1 (176 m), Dh $37(450 \mathrm{~m})$ and Dh $38(405 \mathrm{~m})$ on Kvanefjeld, and Dh I (197 m) in the Narssaq Elv valley. These holes were drilled during the exploration for uranium in the area. The cores consist mainly of radioactive nepheline syenites.

The temperature profiles for the six holes are shown in fig. 5. At the moment 